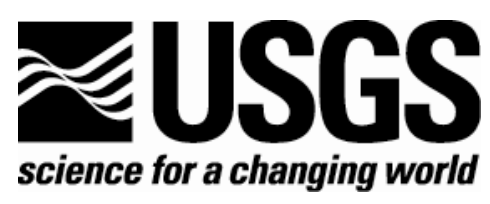

\title{
Amino Acid Racemization in Ostracodes from Bear Lake Cores BL96-1 and BL96-2, Utah and Idaho
}

By Darrell S. Kaufman

Open-File Report 2005-1129

U.S. Department of the Interior

U.S. Geological Survey 


\section{U.S. Department of the Interior \\ Gale A. Norton, Secretary}

\section{U.S. Geological Survey Charles G. Groat, Director}

\section{U.S. Geological Survey, Reston, Virginia 2005}

For sale by U.S. Geological Survey, Information Services

Box 25286, Denver Federal Center

Denver, CO 80225

For more information about the USGS and its products:

Telephone: 1-888-ASK-USGS

World Wide Web: http://www.usgs.gov/

Any use of trade, product, or firm names in this publication is for descriptive purposes and does not imply endorsement by the U.S. Government.

Although this report is in the public domain, permission must be secured from the individual copyright owners to reproduce any copyrighted material contained within this report.

This report has not been reviewed for stratigraphic nomenclature.

Suggested citation:

Kaufman, D.S., 2005, Amino acid racemization in ostracodes from Bear Lake cores BL96-1 and BL96-2, Utah and Idaho: U.S.

Geological Survey Open-File Report 2005-1129, 8p.

Prepared by the U.S. Geological Survey in Denver, Colorado (http://climchange.cr.usgs.gov/) 


\title{
Amino Acid Racemization in Ostracodes from Bear Lake Cores BL96-1 and BL96-2, Utah and Idaho
}

\author{
By Darrell S. Kaufman
}

\section{Introduction}

The ostracode-rich sediment in Bear Lake cores provides an opportunity to evaluate the utility of amino acid racemization for geochronology in a stratigraphically and thermally controlled environment. Because dating lake cores can be difficult for sediments that lack macrofossils or are beyond the range of ${ }^{14} \mathrm{C}$ dating, amino acid geochronology may serve as a useful chronostratigraphic tool in future studies ( McCoy, 1988). This new application of amino acid geochronology is now feasible because the technology needed for routine separation of the right-handed (D) and left-handed (L) forms in microgram quantities of shell has recently become available (Kaufman and Manley, 1998).

Ostracodes are millimeter-size microcrustaceans that secrete a carbonate exoskeleton with a relatively high concentration of proteins. Their shells often are present in sediment cores, allowing amino acid geochronology to be integrated into the study of lake cores. Unlike materials collected from emerged deposits in terrestrial settings, the temperature history of ostracodes recovered in sediment cores taken from below the thermocline of stratified lakes can confidently be assumed to have remained close to $4^{\circ} \mathrm{C}$, the temperature of maximum-density fresh water. Because the rate of transformation of amino acid enantiomers from their L- to Dconfiguration (racemization) is dependent upon temperature, a stable and predictable temperature history is essential to deriving ages.

This study focuses on aspartic acid ${ }^{1}$ (Asp) and glutamic acid (Glu) in the common ostracode genus Candona. These are among the most abundant amino acids in ostracode shell protein (Kaufman, 2000), which reduces sample-size requirements. They also span the range of amino acid racemization rates. Aspartic acid is among the most rapidly racemizing amino acids, which increases the temporal resolution of the technique (for example, Goodfriend, 1992), despite the relatively low ambient temperatures of bottom-water sites. Glutamic acid is one of the most slowly racemizing amino acids (Goodfriend and Meyer, 1991), which suggests that it is well suited to date old material from deep cores. Furthermore, Asp and Glu D/L ratios are the most consistently well-resolved chromatographically, with analytical precision of $\sim 2 \%$ (Kaufman and Manley, 1998). Candona is the most common freshwater ostracode in Bear Lake and is present in many lakes. Because the rate of racemization is somewhat taxon dependent (although 
the rates measured in several taxa are indistinguishable, Kaufman, 2000), using a cosmopolitan genus helps ensure the applicability of these results to other lakes.

\section{Methods}

Ostracodes were recovered from two $\sim 5$-m-long gravity cores from $\sim 40$ and $\sim 50 \mathrm{~m}$ depth in Bear Lake, Utah and Idaho. The shells were prepared according to standard procedure (Kaufman, 2000), and the enantiomeric amino acid composition was analyzed for 343 subsamples of ostracodes using reverse phase HPLC (Kaufman and Manley, 1998). From 3 to 34 subsamples were analyzed from each of 26 levels in the cores, plus an additional 24 subsamples of modern Candona shells, collected live. About one-third of the subsamples comprised $\sim 10-40$ individual shells and weighed $0.1-0.2 \mathrm{mg}$. Following the analysis of these samples, new refinements to the analytical technique (Kaufman, 2000) enabled accurate results to be obtained from a single ostracode shell ( $\sim 5 \mu \mathrm{g}$ of shell per injection), with detection in the subpicomole range. The $\mathrm{D} / \mathrm{L}$ ratios measured in the single shells are indistinguishable from those in multiple-shell preparations. In all, data from 45 subsamples (13 percent of data) were rejected because their amino acid composition showed evidence of contamination by modern amino acids (high concentration of serine relative to glutamic acid, see Kaufman, 2000). The data reported here (table 1) are the mean values of multiple subsamples from each level.

\section{Results}

The results show a monotonic increase in Asp and Glu D/L with increasing depth, with higher $\mathrm{D} / \mathrm{L}$ ratios for Asp compared to Glu (fig. 1). The $\mathrm{D} / \mathrm{L}$ ratios in the uppermost samples are

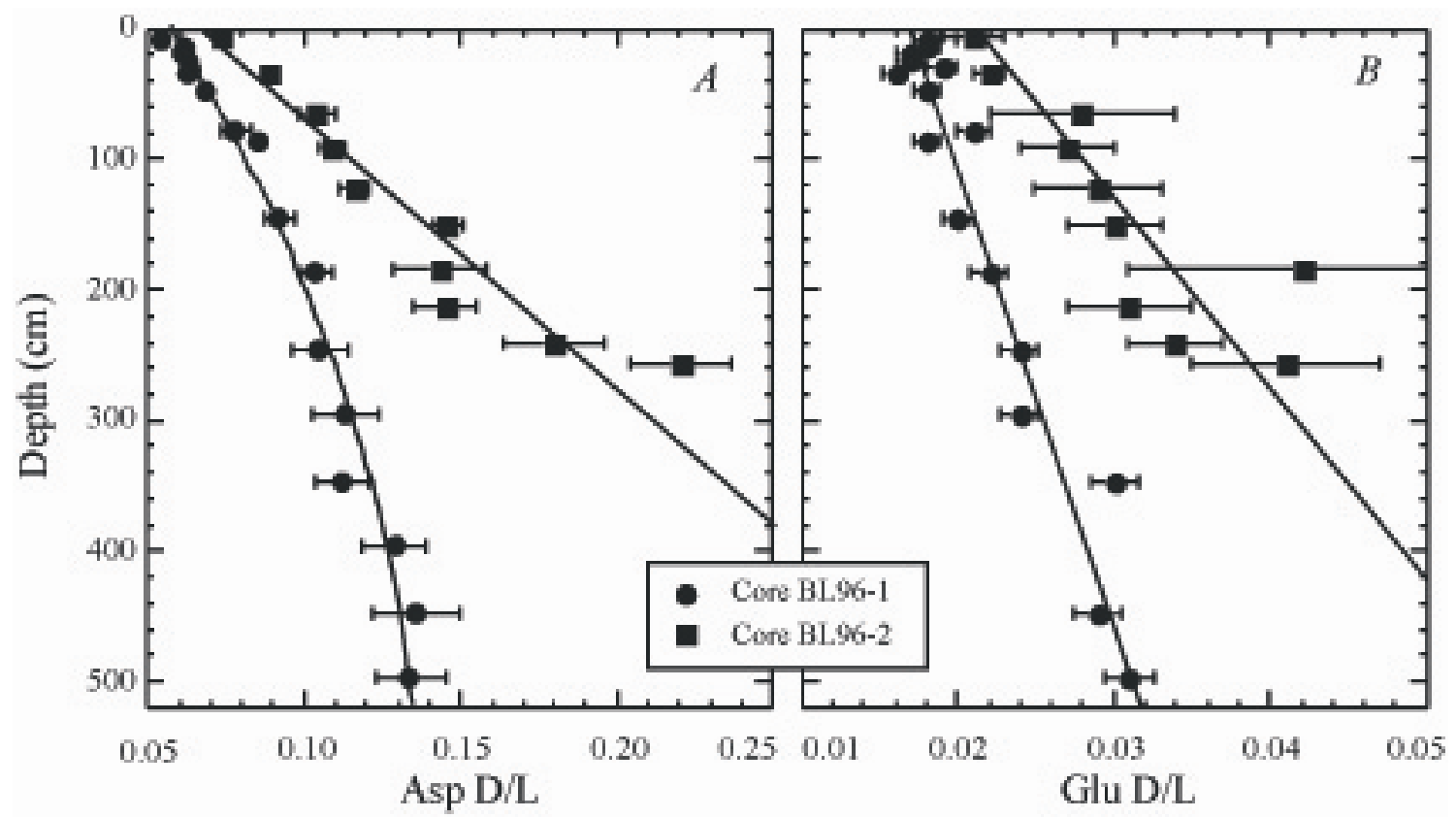

Figure 1. Extent of racemization expressed as the ratio of right-handed (D) to left-handed (L) forms of $(A)$ aspartic acid (Asp), and $(B)$ glutamic acid (Glu) in Candona from Bear Lake cores BL96-1 and BL96-2. Error bars are $\pm 1 \sigma$. Data are listed in Table. 
Table 1. Amino acid results. Aspartic acid (Asp) and glutamic acid (Glu) D/L ratios measured in Candona from Bear Lake cores and in modern Candona collected in springs.

\begin{tabular}{|c|c|c|c|c|c|c|c|}
\hline $\begin{array}{l}\text { Lab ID } \\
\text { (UAL) }\end{array}$ & $\begin{array}{l}\text { Number of } \\
\text { (included) }\end{array}$ & $\begin{array}{l}\text { subsamples } \\
\text { (excluded) }\end{array}$ & $\begin{array}{l}\text { Depth } \\
\text { (cm) }\end{array}$ & $\underset{\text { (mean) }}{\text { Asp D }}$ & $\begin{array}{l}\mathrm{D} / \mathrm{L} \\
( \pm \sigma)\end{array}$ & $\underset{\text { (mean) }}{\text { Glu D/ }}$ & / \\
\hline \multicolumn{8}{|c|}{ Core BL96-I } \\
\hline 2434 & 3 & 1 & 8 & 0.054 & 0.003 & 0.018 & 0.001 \\
\hline 2437 & 5 & 0 & 13 & 0.062 & 0.002 & 0.018 & 0,002 \\
\hline 2435 & 4 & 0 & 18 & 0.060 & 0.002 & 0.017 & 0.001 \\
\hline 2442 & 6 & 0 & 23 & 0.063 & 0.002 & 0.017 & 0.001 \\
\hline 2439 & 3 & 1 & 28 & 0.064 & 0.003 & 0.019 & 0.001 \\
\hline 2441 & 3 & 0 & 33 & 0.063 & 0.001 & 0.016 & 0.001 \\
\hline 2436 & 6 & 0 & 48 & 0.068 & 0.001 & 0.018 & 0.001 \\
\hline 2610 & 10 & 1 & 77 & 0.078 & 0.005 & 0.021 & 0.005 \\
\hline 2594 & 5 & 2 & 87 & 0.085 & 0.003 & 0.018 & 0.005 \\
\hline $2609 / 2593$ & 11 & 0 & 146 & 0.092 & 0.005 & 0.020 & 0.003 \\
\hline 2613 & 7 & 0 & 186 & 0.104 & 0.005 & 0.022 & 0.004 \\
\hline $2595 / 2642$ & 17 & 5 & 246 & 0.105 & 0.009 & 0.024 & 0.004 \\
\hline $2596 / 2643$ & 14 & 6 & 296 & 0.113 & 0.011 & 0.024 & 0.003 \\
\hline $2603 / 2677$ & 6 & 2 & 347 & 0.112 & 0.009 & 0.030 & 0.004 \\
\hline $2604 / 2645$ & 6 & 4 & 397 & 0.129 & 0.010 & - & - \\
\hline $2602 / 2676$ & 10 & 0 & 449 & 0.136 & 0.014 & 0.029 & 0.009 \\
\hline $2601 / 2644$ & 16 & 3 & 497 & 0.134 & 0.011 & 0.031 & 0.004 \\
\hline \multicolumn{8}{|c|}{ Core BL96-02 } \\
\hline 2661 & 8 & 1 & 5 & 0.073 & 0.002 & 0.021 & 0.002 \\
\hline 2662 & 6 & 1 & 35 & 0.089 & 0.001 & 0.022 & 0.001 \\
\hline 2673 & 12 & 2 & 65 & 0.104 & 0.006 & 0.028 & 0.006 \\
\hline 2678 & 8 & 2 & 91 & 0.109 & 0.004 & 0.027 & 0.003 \\
\hline 26663 & 14 & 2 & 121 & 0.116 & 0.005 & 0.029 & 0.004 \\
\hline 2696 & 24 & 0 & 151 & 0.146 & 0.005 & 0.030 & 0.003 \\
\hline $2611 / 2634$ & 25 & 7 & 185 & 0.143 & 0.015 & 0.042 & 0.011 \\
\hline 2695 & 32 & 2 & 212 & 0.145 & 0.010 & 0.031 & 0.004 \\
\hline 2664 & 13 & 3 & 242 & 0.180 & 0.016 & 0.034 & 0.003 \\
\hline \multicolumn{8}{|l|}{ Modem } \\
\hline various & 24 & 0 & - & 0.039 & 0.002 & 0.018 & 0.003 \\
\hline
\end{tabular}

Note: Nearly all samples were made up of mono-specific subsamples (either multiple or single shells). The most common species analyzed was C. spp. 1 shown in Bright and others (2005). In a few cases, shells of two other undocumented species of Candona were analyzed (C. sp. 2 and 3). On the basis of results available to date (Kaufman, 2000; and Kaufman, unpublished data), the $\mathrm{D} / \mathrm{L}$ ratios measured in different species of Candona $\square$ are indistinguishable. 
higher than for modern shells, suggesting that sediment was lost from the core top. The higher ratios at the surface of Core BL96-2, and the more rapid increase in D/L with depth, are consistent with the ${ }^{14} \mathrm{C}$ ages for these cores (Colman and others, 2005). The uncertainty in the $\mathrm{D} / \mathrm{L}$ ratios, as determined by the intershell variability, increases with sample depth. The higher standard deviations for the older shells might reflect the natural variability associated with progressive diagenesis. Small initial differences in the diagenetic reaction network might result in increasingly larger differences in the extent of racemization with time. Alternatively, the extent of sediment mixing by bioturbation might have decreased through the Holocene. Because the sediment is massive throughout the core, we have no evidence to exclude reworking.

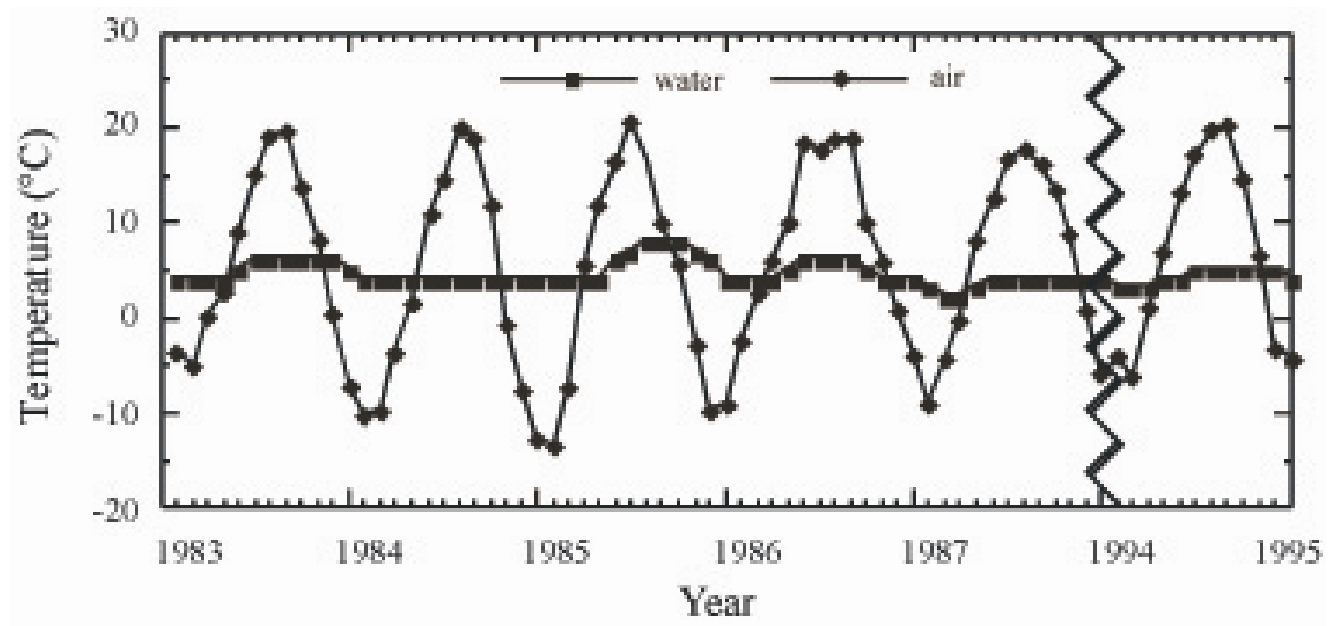

Fig. 2. Monthly temperature of Bear Lake bottom water and air temperature at Lifton, Idaho. Lake temperature data from Wurtsbaugh and Luecke (1995, and written communication); air temperature data from Utah State University Climate Center. Note the break in the time series between 1988 and 1994.

\section{Discussion}

Once these data are combined with the ${ }^{14} \mathrm{C}$ age model for these cores, they will be used to derive a calibrated age equation for racemization in Candona at the temperature of Bear Lake bottom water. Water temperature of Bear Lake was measured during 6 years, between 1983-88 and 1994-1995 (Wurtsbaugh and Luecke, 1995, and Wurtsbaugh and Luecke, written communication). Abyssal water from 40 to $60 \mathrm{~m}$ (the lake bottom) during 5 of 6 years fluctuated in the narrow range of $3.0^{\circ}$ to $5.5^{\circ} \mathrm{C}$, with a mean annual temperature of $4.6 \pm 0.7^{\circ} \mathrm{C}$ (fig. 2 ). This compares to air temperatures at the north end of the lake that typically experienced seasonal temperature fluctuations of $30^{\circ} \mathrm{C}$ (based on mean monthly records obtained from the Utah State University Climate Center) (fig. 2). Stormy conditions during spring turnover of 1985 caused relatively warm water (up to $8^{\circ} \mathrm{C}$ ) to penetrate the hypolimnion and reside at the lake bottom until late fall. Because the amplitude of seasonal and interannual temperature fluctuations is typically $< \pm 1{ }^{\circ} \mathrm{C}$ at the depth of the core sites, the difference between the arithmetic mean annual temperature and the effective diagenetic temperature is negligible (Miller and Brigham-Grette, 1989). Furthermore, the size of temperature fluctuations sensed in the subbottom sediment generally is less than at the that of the overlying water because: (1) the sediment/water mixture that blankets some lake bottoms tends to isolate the lake bottom from temperature changes, 
however minor, in the main body of the bottom water (for example, Pugh, 1977); and (2) the temperature wave is attenuated exponentially with depth below the lake bottom (for example, Wang and others, 1986). Upon deeper burial, to many tens of meters, thermal conditions become increasingly controlled by the geothermal flux (for example, Katz and others, 1979; Bada and Man, 1980).

\section{Conclusion}

The data presented in this study demonstrate the feasibility of using amino acid racemization in ostracodes for geochronology. The sample size required for an analysis is an order of magnitude less than for AMS ${ }^{14} \mathrm{C}$ dating and presents a new opportunity to derive ages for deposits that are organic poor or suffer from large ${ }^{14} \mathrm{C}$ reservoir effects. Because ostracodes are common in subaqueous depositional settings, the technique can be integrated into studies of lake sediment cores. These environments are ideally suited for amino acid geochronology because, unlike materials collected from emerged deposits, the temperature history of ostracodes recovered in sediment cores from deep lacustrine and marine settings can be estimated confidently within narrow limits.

\section{Footnote}

${ }^{1}$ During laboratory hydrolysis under $\sim 6 \mathrm{M} \mathrm{HCl}$, any asparagine (Asn) in fossil proteins undergoes deamidation to Asp (Zhao and others, 1989) and glutamine (Gln) is transformed to Glu. The Asp and Glu results might, therefore, include some component of Asn and Gln, which was converted during sample preparation.

\section{Acknowledgements}

Jordon Bright and Rick Forester identified the ostracodes; Jordon Bright prepared the samples for amino acid analysis and assisted in the laboratory. Funding was provided through National Science Foundation grant EAR-9896251 and the Earth Surface Dynamics Program of the U.S. Geological Survey.

\section{Literature Cited}

Bada, J.L., and Man, E.H., 1980, Amino acid diagenesis in deep sea drilling project cores: Kinetics and mechanisms of some reactions and their applications in geochronology and in paleotemperature and heat flow determinations: Earth Science Reviews, v. 16, p. 21-55.

Bright, J. and Forester, R. and Kaufman, D., 2005, Obstracode Analysis for Cores BL96-1 and BL96-2 from Bear Lake Utah and Idaho, U.S. Geological Survey Open-File Report \#\#\#\#.

Colman, S., Kaufman, D., Rosenbaum, J.G., and McGeehin, J.P., 2005, Radiocarbon dating of cores collected in Bear Lake, Utah and Idaho, Geological Survey Open-File Report \#\#\#\#. 
Goodfriend, G.A., 1992, Rapid racemization of aspartic acid in mollusc shells and potential for dating over recent centuries: Nature, v. 357, p. 399-401.

Goodfriend, G.A., and Meyer, V.R., 1991, A comparative study of the kinetics of amino acid racemization/epimerization in fossil and modern mollusk shells: Geochemica et Cosmochimica Acta, v. 55, p. 3355-3367.

Katz, B.J., Harrison, C.G.A., and Man, E.H., 1979, The effects of the geothermal gradient on amino acid racemization: Earth and Planetary Science Letters, v. 44, p. 279-286.

Kaufman, D.S., 2000, Amino acid racemization in ostracodes, in Goodfriend, G., Collins, M., Fogel, M., Macko, S., and Wehmiller, J., eds., Perspectives in Amino Acid and Protein Geochemistry: Oxford University Press, New York, p. 145-160.

Kaufman, D.S., and Manley, W.F., 1998, A new procedure for determining enantiomeric (D/L) amino acid ratios in fossils using reverse phase liquid chromatography: Quaternary Science Reviews (Quaternary Geochronology), v. 17, p. 987-1000.

McCoy, W.D., 1988, Amino acid racemization in fossil non-marine ostracod shells-A potential tool for the study of Quaternary stratigraphy, chronology, and palaeotemperature, in DeDeckker and others, eds, Ostracodes in the Earth Sciences, Elsevier, p. 219-229.

Miller, G.H., and Brigham-Grette, J., 1989, Amino acid geochronology-Resolution and precision in carbonate fossils: Quaternary International, v. 1, p. 111-128.

Pugh, D.T., 1977, Geothermal gradient in British lake sediments: Limnology and Oceanography, v. 22, p. 581-596.

Wang, K., Shen, P.Y., and Beck, A.E., 1986, On the effects of thermal properties structure and water bottom temperature variation on temperature gradient in lake sediments: Canadian Journal of Earth Sciences, v. 23, p. 1257-1264.

Wurtsbaugh, W., and Luecke, C., 1995, Examination of the abundance and spatial distribution of forage fishes in Bear Lake (Utah/Idaho): Unpublished progress report to the Utah Division of Wildlife Resources, Project F-47-R Study 5, 69 pp.

Zhao M., Bada, J.L., and Ahern, T.J., 1989, Racemization rates of asparagine-aspartic acid residues in lysozyme at $100^{\circ} \mathrm{C}$ as a function of $\mathrm{pH}$ : Bioorganic Chemistry, v. 17, p. 36-40. 